\title{
TAVSHEDENS KONFIGURATION
}

\author{
Hiv, aids og frygten for social død i Sydafrika
}

\section{BJARKE OXLUND}

I Sydafrika lever mere end fem millioner mennesker med hiv eller aids (UNAIDS 2010). Dermed tager landet prisen som den nation i verden, der har det største antal smittede i faktiske tal, men til trods for en national prævalens på over 20 procent og næsten to årtiers aids-kampagner under sloganet Bryd tavsheden er mellemmenneskelig kommunikation om hiv og aids til stadighed omgærdet af hemmelighedskræmmeri, benægtelser og tavsheder. I hiv- og aids-litteraturen omtales denne tavshed slet og ret som stigma ud fra en læsning inspireret af sociologen Erving Goffmans klassiske værk om samme (1963), og hvor stigmatiseringen primært forklares med henvisning til sex som tabu. Imidlertid har tiden efter apartheidstyrets fald i 1994 også været en periode, hvor den sydafrikanske offentlighed har været vidne til en veritabel eksplosion af seksuel frigørelse i form af frigivelse af pornografi, indførelsen af grundlovssikrede rettigheder for seksuelle minoriteter og brugen af nøgne kroppe og seksualiserede budskaber $\mathrm{i}$ alle typer af medier (Posel 2004). Denne samtidighed af tavshed og italesættelse repræsenterer på mange måder et paradoks, som påkalder sig en dybere udredning og forklaring.

Med udgangspunkt i mit ét år lange ph.d.-feltarbejde om unge mænds sexog kærlighedsliv i en kontekst karakteriseret af hiv og aids i Limpopo-provinsen i Sydafrika (Oxlund 2009a) vil denne artikel vise, at den anspændthed, som hiv- og aids-epidemien har bragt med sig, snarere relaterer til døden som tabu end til en tabuisering af seksualitet som sådan. Således anses en positiv hiv-test for at blokere for en persons sociale tilblivelse, mens et aktivt sexliv ofte fejres og italesættes som et kardinalpunkt for social tilblivelse. Gennem en analyse af, hvorfor unge mænd og kvinder ved Limpopo Universitet generelt ikke ønsker at kende deres hiv-status, udvikler artiklen et argument om de moralske implikationer, som en positiv test har for den enkelte i relation til slægtskab og andre fællesskaber. Inspireret af den klassiske antropologis analyser af urenhed (Douglas 
1966) og dårligdom (Evans-Pritchard 1936) anskuer jeg den udfordring, der udgøres af hiv og aids, som et spørgsmål om usikkerhed og fare i en lokal moralsk verden (Kleinman 1999, 2006).

Analysen viser, at den tavshed, der omgærder hiv og aids i Sydafrika, ikke udelukkende kan forklares med benægtelse og frygt for stigmatisering. Tavsheden tjener nemlig det formål at generere håb og modvirke social død, hvilket må ses i sammenhæng med de unges identitet og forståelse af sammenhængen mellem krop og psyke samt de politiske forhold i postapartheid Sydafrika.

\section{Politik og videnskab}

Den sydafrikanske hiv/aids-krise har ikke alene været en epidemiologisk karakter. Som den uden sidestykke største trussel mod befolkningens helbredstilstand i nyere tid har epidemien været kilde til en politisk og videnskabelig disputs om ætiologi, ${ }^{1}$ der samtidig har været en forhandling og fortolkning af betydningen af arven fra apartheid og den tætte sammenhæng mellem fattigdom og raceforhold. I kraft af den økonomiske og politiske isolation, der var resultatet af det internationale samfunds boykot af apartheidstyret i 1980'erne, kom epidemien både sent og langsomt til Sydafrika sammenlignet med andre regioner i Afrika syd for Sahara. Da Nelson Mandela som den første sorte politiker indtog det sydafrikanske præsidentembede i 1994, figurerede hiv og aids derfor ikke højt på den afrikanske nationalkongres, ANC's, politiske dagsorden. Det kom til at betyde, at Sydafrika spildte vigtig tid i den anden halvdel af 1990'erne i forhold til at lancere en effektiv forebyggelsesindsats, som kunne have reddet mange menneskeliv.

I årene efter årtusindeskiftet kom Nelson Mandelas efterfølger i præsidentembedet, Thabo Mbeki, og hans sundhedsminister, Manto Tshabalala-Msimang, til at trække overskrifter verden over. Som såkaldte hiv/aids-dissidenter, der betvivlede den ortodokse videnskabelige forståelse af sammenhængen mellem hiv og aids, forbød Mbeki og Tshabalala-Msimang udbredelsen af antiretroviral medicin, der skulle forhindre transmission af hiv fra gravide kvinder til deres børn, mens de i stedet promoverede rødbeder, afrikanske kartofler, hvidløg og vitaminer som den rette behandling. Således blev kampen om hiv og aids i Sydafrika mere og mere spektakulær i kraft af den eksplosive vækst i medlemmer af Treatment Action Campaign (TAC), som endte med at fremstå som en af de mest indflydelsesrige pressionsgrupper for civile rettigheder i landets historie (Leclerc-Madlala 2005: 849-50). I første omgang arbejdede TAC med stor succes sammen med ANCregeringen om at udfordre den internationale medicinalindustri med henblik på

at skaffe billigere lægemidler, men da Mbeki og Tshabalala-Msimang modarbejdede udbredelsen af hiv/aids-medicin på offentlige sundhedsfaciliteter, endte TAC 
med at bruge kræfter på at bekæmpe regeringen og dens hiv/aids-politik snarere end den internationale medicinalindustris prispolitik (Robins 2008:188-9). ${ }^{2}$

Debatmiljøet i det sydafrikanske hiv/aids-landskab har således været intenst og højlydt på det politiske plan, og til trods for politisk modvilje fra både præsident og sundhedsminister i forhold til medicinsk behandling i årene 1999-2008 har den sydafrikanske regering med international støtte lanceret den ene gigantiske oplysningskampagne efter den anden med særligt fokus på unge menneskers brug af kondom som prævention i forhold til både hiv og uønsket graviditet. Selv om de politiske slagsmål og store kampagneindsatser har fyldt meget $\mathrm{i}$ både nationale og internationale medier, forholder det sig sådan, at ude i de landsbyer og townships, hvor flertallet af den sorte befolkning lever, er hiv og aids fortsat omgærdet af tavshed, hemmeligholdelse og fortielse på det mellemmenneskelige plan.

\section{Renhed og urenhed}

Som antropologen Jarrett Zigon har bemærket, er hiv/aids et af de mest moralsk ladede forskningsfelter, som en antropolog kan kaste sig over (Zigon 2008:111). I hiv/aids-organisationernes sprogbrug omtales disse moralske dimensioner ofte lettere forsimplet og psykologisk individualiserende som stigma eller fortrængning (se Thornton 2008). Imidlertid har disse begreber en tendens til at adskille de moralske dimensioner af hiv og aids fra andre moralske felter, hvilket ikke kan retfærdiggøres med henvisning til de erfaringer, som unge sydafrikanere gør sig i deres hverdagsliv. Problemet ved at anvende begreberne er derfor, at det tages for givet, at vi allerede på forhånd ved, hvad der er på spil for folk (jf. Kleinman 1999:70), og at vi derfor ikke gør os umage med at finde ud af, hvad der konstituerer den lokale udgave af, hvad der udgør et moralsk felt (Kleinman 2006:2). I sin bog Purity and Danger skrev antropologen Mary Douglas om moralitet og urenhed, at:

Vi må starte med at anerkende, at moralske situationer ikke er lette at definere. Som oftest er de mere obskure og modsætningsfyldte, end de er klart definerede. Det er den moralske regels natur at være generel, og dens applikation på en bestemt kontekst vil derfor altid være usikker (Douglas 1966:161).

I denne artikel vil jeg derfor særligt prioritere de uvisheder, der omgærder hiv og aids, såvel som de forbindelser, der kan trækkes mellem moralske spørgsmål og lokale forståelser af urenhed (defineret som faren ved uorden) (ibid.). Men hvor Douglas i en funktionalistisk forstand beskrev, hvordan regler for urenhed kan hjælpe med at afgøre ambivalente moralske forhold (op.cit.161), er den pointe, 
som jeg gerne vil fremskrive, snarere den, at forestillinger om renhed og urenhed også kan bidrage til at opretholde et ønskværdigt niveau af uvished og ambivalens. I min argumentation for, at hiv og aids udgør en moralsk trussel og eksistentiel fare og ikke blot et politisk spørgsmål om prævalens, CD4-tal eller adgangen til antiretroviral medicin, vil jeg vise, hvordan unge mennesker i Limpopo bruger uvished om deres hiv-status til at opretholde deres sociale råderum.

Gennem en præsentation af flere hændelsesforløb og sygdomsberetninger er det således ambitionen med den øvrige del af artiklen at analysere de forklaringsrammer, som mange sorte sydafrikanere i Limpopo trækker på, når de skal skabe mening i den trussel mod deres sociale liv og fysiske og psykiske helbred, som hiv og aids udgør.

\section{Kifilwes sygdom og død}

Kifilwe Moganes heftige hoste skar igennem stilheden næsten hver nat i november 2006, når hun gik sine runder på den del af Turfloop campus, hvor jeg boede. Limpopo Universitet havde udliciteret sikkerhedstjenesten til en privat udbyder, Urban Security, og Kifilwe var én ud af flere hundrede lavt betalte vagter, som kontrollerede de tre hovedindgange til campus, og som var indsat ved næsten hver eneste bygning for at beskytte universitetets ejendom og for at skabe et sikkert miljø for studerende og ansatte. Kifilwe, som var omkring tredive år gammel, ugift og uden børn, boede i et lejet værelse i en nærliggende township. Oprindeligt kom hun fra en landlig township, der lå to timers kørsel fra Turfloop campus, og hvor hendes mor stadig boede. I løbet af et par uger bevidnede hendes kolleger og jeg, hvordan Kifilwes helbred blev ringere dag for dag, og hvordan hun blev tyndere og tyndere, alt imens hun drak madolie for at lindre sine smerter. ${ }^{3} \mathrm{Ud}$ over sine fysiske smerter var Kifilwe også involveret $\mathrm{i}$ et juridisk slagsmål med en lokal kvinde, som havde anklaget hende for at have en affære med hendes mand.

I et par dage var vi flere, som talte med Kifilwe om hendes tilstand, dens årsag og de muligheder, som hun havde for at opsøge behandling. Kifilwe selv afviste at opsøge det nærliggende Mankweng Hospital, som er et offentligt hospital, der tilbyder gratis ydelser, herunder hiv-test og behandling med aids-medicin. Som årsag til denne afvisning fremhævede hun, at man på hospitalet kun kunne få en behandling af ringe kvalitet. En anden mulig grund kunne være, at mange af universitetets studerende arbejdede som praktikanter på Mankweng Hospital, hvilket de studerende ofte nævnte som en grund til ikke at opsøge netop denne facilitet i forbindelse med graviditet og seksuelt overførte sygdomme. Kifilwes månedsløn på 1.400 rand (cirka 1.000 kroner) gjorde hende imidlertid ikke i 
stand til at betale de 250 rand, som en konsultation kostede på den billigste private lægeklinik i lokalområdet. Da hun en morgen begyndte at hoste blod, tilbød jeg at køre hende til hendes foretrukne sundhedsudbyder og at betale omkostningerne. Da hun kom tilbage fra konsultationen til venteværelset, hvor jeg sad, udtrykte Kifilwe med det samme, at hun ønskede at drage hjem til sin mor, og hun sagde med fortvivlet stemme, at hun ,aldrig ville komme tilbage til Turfloop og Mankweng“, fordi hun skulle „hjem og dø“. Kifilwe drog hjem til sin mor, og i løbet af de næste par uger talte jeg med hende over telefonen flere gange. Det endte med, at hun på sin mors foranledning blev indlagt på et hospital i hovedstaden Pretoria, og den sidste gang, vi talte sammen, sagde Kifilwe til mig: „Lægerne siger, at det ikke er hiv/aids, det er ikke tuberkulose, det er ikke diabetes. Alt skal nok blive godt!“

To uger senere modtog jeg den triste nyhed, at Kifilwe var død, og flere af hendes kolleger og bekendte på universitetet gjorde forberedelser til at rejse de 200 kilometer for at deltage i begravelsen. Jeg spurgte én af dem, hvad hun tænkte om Kifilwes sygdom og død, og blev overrasket, da hun uden overvejelse prompte svarede: „Den kvinde var alt for glad for sex.“ Jeg forstod udsagnet som en markering af, at i denne ven og kollegas forståelse kunne Kifilwes død henføres direkte til aids-relaterede symptomer.

Umiddelbart kan dette anskues som en bekræftelse af den udbredte forestilling om, at hiv- og aids-relateret stigma hænger sammen med det forhold, at hiv som oftest er seksuelt overført, hvilket stemmer overens med Goffmans identifikation af stigma som en plet på den individuelle karakter, ofte forbundet med en negativ moralsk vurdering af individets drifter (Goffman 1963:4). En forståelse af sex som tabu og stigmafremkaldende fænomen kan imidlertid ikke stå alene som forklaring, idet seksualiteten også har mange positive betydninger og konnotationer såsom styrke, nydelse, fertilitet og social reproduktion.

\section{Sex og stigma}

De sydafrikanske socialhistorikere Peter Delius og Clive Glaser argumenterer for, at førægteskabelig sex i tiden før apartheid blandt sorte sydafrikanere blev opfattet som et problem på grund af børn født uden for ægteskab og ikke på grund af den seksuelle akt som sådan (Delius \& Glaser 2005:30). De argumenterer yderligere for, at det var indførelsen af kristendommen, der endte med at indhylle seksualiteten i tavshed og skam, og som senere bidrog til den stigmatisering, som associeres med hiv og aids i dag (op.cit.33). Delius og Glaser udfordrer derfor antagelsen om, at hiv- og aids-relateret stigma i Sydafrika kan henføres direkte til individuel skam, og foreslår i stedet, at kilderne til stigmatisering er flerdi- 
mensionelle og forbundet med forestillinger om urenhed, hekseri og populære forståelser af smitte (Delius \& Glaser 2005:29; se også Das 2001:1; HammondTooke 1993:169-83; Niehaus 2002:189-91). Disse indsigter ansporer til at lede efter betydningen af stigma på et socialt niveau snarere end på et individuelt niveau, hvilket delvis bryder rammen for Goffmans tilgang til stigma.

Antropologen Veena Das har således påpeget, at Goffmans samordnende begreb om den spolerede identitet og håndteringen af samme drejede hans analyse i retning af en meget individualistisk forståelse af stigma (Das 2001:1). På den måde blev Goffmans begrebsliggørelse af stigma fattig på kulturel betydning, hvilket samtidig gjorde det muligt at negligere det kollektive niveau og de værdimæssige uoverensstemmelser i hverdagslivet. I henhold til min egen viden og erfaring er det denne individualiserede og kontekstuafhængige definition af stigma, der har ligget til grund for store dele af det arbejde, som mange udviklingsorganisationer udfører i forhold til, hvad de ofte betegner som afstigmatisering. Organisationerne har en tendens til at ignorere de lokale moralske verdener, som de arbejder i, hvilket gør, at programmerne i stedet for at føre til, hvad de betegner som en reduktion i stigma, måske snarere forstærker stigmatiseringen. Alene ved at tale om stigma som en størrelse, der baseret på spørgeskemaundersøgelser kan placeres på en skala (se fx Durden 2008:11), risikerer man at objektivere stigma som en målbar størrelse (se fx Kalichman et al. 2005; Forsyth et al. 2008; www.stigmaindex.org). Man får dermed ikke at vide, hvorfor respondenten ikke ønsker at spise mad tilberedt af en person, der lever med hiv, eller at lade sine børn modtage undervisning af en hiv-positiv lærer. Man får heller ikke at vide, hvordan respondenten opfatter personer, der lever med hiv, eller hvordan de forestiller sig, at vedkommendes hiv-status er opstået.

I diskussionen af disse fænomener er det vigtigt at holde sig for øje, at stigma og smitte er distinkte begreber, hvor stigma ifølge Das refererer til oplevelsen af at blive brændemærket på kroppen af en tilstand, som adskiller én fra mængden, mens smitte udgør potentialet for, at en tilstand overføres fra en person til en anden (Das 2001:5). Goffmans stigmabegreb er således yderst relevant i forhold til at beskrive generelle sociale sanktioner mod folk, der befinder sig i velkendte tilstande, mens reaktionen på smittefare formentlig bedre kan indfanges ved at tænke gennem urenhed og forurening. Hvis vi ihukommer den bemærkning om en overdreven seksuel lyst, som en kollega ytrede som reaktion på Kifilwes sygdom og død, er det muligt at forstå den som et udsagn om et brud på sociale normer, hvilket på det lokale sotho-sprog er associeret med varme og hede (fǐs $a$ ).

Antropologen David Hammond-Tooke (1993:181) har udførligt beskrevet, hvordan denne hede i en symbolsk forstand er knyttet til fænomener som døden eller grænseoverskridende seksualitet, mens den i en mere konkret forstand er knyttet til en kropslig tilstand af feber. At være hed producerer en tilstand af 
urenhed (ditšhila), som i sin yderste konsekvens vil få en person til at visne bort (Mönnig 1967:67; Niehaus 2001; Hammond-Tooke 1981:121). Adskillige faktorer taler for, at en fortolkning af kollegaens kommentar om Kifilwes sygdom med fordel kan tage udgangspunkt i denne forståelse: Som en enlig, barnløs kvinde i trediverne, der boede alene langt fra sin slægt, besad Kifilwe seksuelle og reproduktive kræfter, som ikke var kanaliseret $\mathrm{i}$ en passende retning $\mathrm{i}$ henhold til sotho-forestillinger om, hvordan en voksen kvinde skal leve sit liv. Til trods for at Kifilwes job hørte til i den absolut lavest lønnede del af arbejdsmarkedet, var hun en uafhængig kvinde, der forsørgede sig selv og ikke var underordnet et mandligt overhoved $i$ et hushold. Kombineret med anklagen om, at hun skulle have været involveret med en gift mand, rummede Kifilwes situation således en række forhold, der på forskellig vis overskred gældende normer for kønnet adfærd i den lokale kontekst.

I min forståelse var det derfor ikke de formodede seksuelle aktiviteter som sådan, der var forkerte, men snarere omstændighederne, hvorunder den formodede sex havde fundet sted, der afstedkom stigmatisering og skam. Hvorvidt Kifilwe døde af aids-relaterede symptomer er i og for sig uvæsentligt for betydningen af denne historie. Dens betydning ligger snarere i det faktum, at et antal mennesker i hendes umiddelbare omgivelser tænkte, at dette var tilfældet, og i stilhed fældede en moralsk dom over hendes personlige karakter. Dette er sigende for den måde, hvorpå folk i en sydafrikansk sammenhæng ofte udleder en diagnose fra et antal observationer af en persons kropslige forandringer og sociale adfærd (forestillet eller virkelig), mens de samtidig opretholder en offentlig tavshed med hensyn til kilden til vedkommendes sygdom og efterfølgende død. Dette får mig til at spekulere på, om uvisheden ved ikke at kende Kifilwes hiv-status og den akkompagnerende tavshed var vigtig for hendes venner og kolleger i forhold til at tage til begravelsen og vise deres sidste respekt: Ville de være taget af sted, hvis de havde vished for, at hun var død af aids-relaterede symptomer? Og hvad med Kifilwe - vidste hun det selv, og ville det have været nyttigt for hende at kende sin hiv-status? I et senere afsnit vil jeg gennem analysen af en mandlig studerendes case argumentere for, at mange sotho-talende sydafrikanere anser det for gavnligt ikke at kende deres hiv-status. Inden da skal vi imidlertid dvæle lidt ved det paradoksale i, at denne sociale tavshed udspiller sig i et landskab, der er gennemsyret af hiv- og aids-oplysningskampagner.

\section{Paradoksal kommunikation}

Det niveau af hemmelighedskræmmeri og tavshed, som jeg oplevede i forhold til hiv og aids i Limpopo, er overraskende, i den forstand at Sydafrika har været 
vidne til en veritabel eksplosion af hiv- og aids-relaterede oplysningskampagner hen over det seneste tiår. De nationale tv-stationer viser sæbeoperaer, hvori der indgår uddannelseselementer (såkaldt edu-tainment), uddannelsesinstitutioner er plastret til med kondombeholdere, og den nationale LoveLife-kampagne med særligt fokus på teenagere har opsat gigantiske plakater i hele landet, trykt ungdomsmagasiner i millionvis og åbnet det ene ungdomscenter efter det andet for at træne ung til ung-vejledere. I forlængelse heraf er der ikke et eneste offentligt sted på Turfloop campus, hvor man ikke kan øjne hiv- og aids-relateret kommunikation i én eller anden form, og den lokale radiostation, Thobela FM, som hører til på campus, udsender også beskeder og programmer om forebyggelse af hiv og aids. En af de kvindelige studerende sagde således i en gruppediskussion, at ,regeringen og medierne har gjort nok“.

Men dette til trods svarede 49,9 procent af de 1.823 førsteårsstuderende ved Limpopo Universitet, som udfyldte et spørgeskema i forbindelse med deres studiestart i årene 2004, 2005, 2006 og 2007, at de ikke havde brugt kondom ved deres seksuelle debut, mens 40,2 procent svarede, at de ikke havde brugt kondom sidste gang, de havde sex. Disse tal er tankevækkende i en provins, hvor lidt mere end hver femte voksne person lever med hiv (DoH 2006:11). Så alt imens den kvindelige studerende havde ret $\mathrm{i}$, at hiv/aids-forebyggelse har fyldt kolossalt meget i medie- og gadebilledet, er der også en pointe i, at aids i Sydafrika er blevet produceret som et fænomen omgærdet af hemmeligholdelse, tavshed og fornægtelse i relation til konkrete individer, sådan som antropologen Graeme Reid og sociologen Liz Walker har beskrevet det (Reid \& Walker 2003:85).

Historikeren Robert Morrell har ligeledes bemærket, hvordan ti års oplysningskampagner under sloganet „Bryd tavsheden“ ikke har kastet de ønskede resultater af sig (Morrell 2003:41). Samtidig har også den humanistiske og den socialvidenskabelige forskning i Sydafrika haft et større fokus på de videnskabelige og politiske slagsmål over hiv og aids (Nattrass 2004, 2007; Posel 2008; Fourie 2006; Cameron 2005; van der Vliet 2004), end de har haft på studiet af den sociale betydning, som hiv og aids antager i konkrete sociale miljøer, hvor almindelige mennesker har været overladt med den opgave at håndtere en epidemi, som rammer på tværs af sociale og geografiske skel.

Som nævnt har mange lokalsamfund svaret på krisen med tavshed, hvilket også har gjort det metodisk svært for de forskere, der rent faktisk har prøvet at udføre kvalitativ forskning om de sociale aspekter af hiv og aids. Eksempelvis har antropologen Jonathan Stadler udført feltarbejde i en tsongalandsby i Limpopo, hvor hemmelighedskræmmeri, omgåelse og benægtelse af hiv og aids udgjorde væsentlige barrierer for hans undersøgelse (Stadler 2003:130). Stadler bemærker, hvordan dødsfald altid blev efterfulgt af spekulation og mistanke om aids, alt imens den offentlige tavshed blev opretholdt i forbindelse med selve begravelses- 
ritualet (ibid.). På campus blev studerendes aids-relaterede dødsfald også annonceret i vage termer såsom, at nogen var død efter kort tids sygdom. På den måde var det svært for mig at vide med sikkerhed, hvornår nogen var død af aids-relaterede symptomer eller af noget helt andet. Samtidig var den eufemistiske brug af vendingen, at nogen var død efter kort tids sygdom, blevet et genkendeligt tegn på en aids-relateret død, hvilket gjorde det muligt for folk på anden vis at kommunikere det, som ikke kan siges direkte (Thornton 2008:150; se også Stadler 2003:127; Posel 2007:70; Ashfort 2002:121). I et medielandskab bombarderet med hiv- og aids-kommunikation og karakteriseret ved en åben diskussion af seksualitet fremstår disse tavsheder og omgåelser særligt manifeste og kalder på en analyse af, hvordan de hænger sammen med forståelser af moral og sygdom.

\section{Hiv og hekseri}

Baseret på studier i den store Johannesburg-bydel Soweto har antropologen Adam Ashfort argumenteret for, at hiv-relateret tavshed og stigma i Sydafrika kan forstås ud fra forestillinger om hekseri: „Det er svært at forestille sig en sygdom eller et kompleks af symptomer, som ville passe bedre til hekseriparadigmet end aids“ (Ashfort 2002:128; min oversættelse). Andre antropologer har påpeget, at selv om mange sorte sydafrikanere generelt frygter hekseri, er det få, der rent faktisk kæder specifikke aids-forløb sammen med hekseri (Niehaus \& Jonsson 2005:181; Stadler 2003:132; også Delius \& Glaser 2005:35). Stadler (2003:131) foreslår fx, at det er mere nyttigt at tænke på hekseri som en moralsk metafor, der kan fungere som en analogi for forståelsen af aids-pandemien.

Spørgsmål om årsagen til sygdom kalder ofte på fortællinger om, hvordan sygdommen opstod snarere end på entydige kategoriseringer. Forskellige tilstande kan fremstilles i den samme narrative struktur eller ramme, selv om symptomer og årsager ikke nødvendigvis er de samme (Steffen \& Jessen 2002:28). For lægfolk er det vigtigste sjældent at være i stand til at foretage absolutte kategoriseringer af sygdom, som hvis man eksempelvis hævder, at hiv og aids er en konsekvens af hekseri. Snarere er det vigtigt for folk at forme en sammenhængende narrativ struktur, der er både meningsfuld og instruktiv i forhold til at gøre noget. At forstå hiv og aids i Sydafrika handler derfor mere om at forstå de lokale moralske implikationer (Farmer 1992:109), end det handler om at kontrastere forestillinger om hekseri med videnskabelige forklaringer (Zigon 2008:112).

Lokale forestillinger om, hvad der ligger bag dårligt helbred eller dårligdom (jf. Evans-Pritchard 1936), blev imidlertid åbenbare for mig, når studerende ved Limpopo Universitet diskuterede, hvorvidt muthi (traditionel urtemedicin afledt af zulu-ordet for træ - se Ngubane 1977:22) eller hekseri var inde i billedet, selv 
om jeg aldrig direkte hørte nogen sige, at hiv-aids kan henføres direkte til hekseri som sådan. I nogle enkelte tilfælde henviste studerende til andre kilder, der sagde, at hiv/aids var forårsaget af hekseri, som da en ung mand sagde følgende i en gruppediskussion:

Nogle af præsterne siger nogle gange, at aids ikke er ligesom en fysisk sygdom, men at det i højere grad er en spirituel ting. De kan finde på at sige, at hekse har angrebet dig, [...] og at du har aids, selv om du aldrig har været i seng med nogen [...]. Så det er en tro på, at hekseri også spiller en rolle i overførslen af hiv.

Ved samme lejlighed sagde en anden ung mand: „Fra et kulturelt synspunkt, der tager man det som en forbandelse. Det er stadig forbundet med en dårligdom, som om man er forhekset.“

Makgotla på 22 år, som jeg spillede fodbold sammen med, fortalte mig følgende under et individuelt interview:

Blandt os sorte tror vi alt for meget på hekseri, forstår du? Hvis nogen er syg, så er den første mistanke, man får, at vedkommende er blevet forhekset. Det, vi siger om den person, er, at folk ved, at hr. sådan og sådan kunne ikke lide ham eller hende. Det er den første mistænkte [for hekseri].

Direkte adspurgt om han selv mente, at hiv/aids er forårsaget af hekseri, svarede Makgotla: „Nej, det kan jeg ikke forestille mig, fordi den virus - hiv - den findes i blodet. Hvordan skulle man være i stand til at putte noget i dit blod uden dit samtykke?"،

Nogle studerende trak direkte på deres naturvidenskabelige træning, når de helt og fuldt afviste ideen om, at hekseri og hiv/aids skulle have noget med hinanden at gøre, mens andre studerende grublede over dårligdomme og uheld på et mere generelt plan. Særligt studerende, som var tilhængere af Den Zionistiske Kristne Kirke (ZCC), introducerede i interviews og fokusgrupper forklaringer, hvor hekseri, moralske afvigelser og symbolsk urenhed var inde i billedet. Dette er ikke overraskende, eftersom ZCC er en uafhængig afrikansk kirke, der anerkender forfædreånder og hekse som virksomme kræfter i verden (Anderson 1999:290). Blandt de studerende ved Limpopo Universitet var det mere end hver fjerde, som tilhørte dette kirkesamfund.

George, en 22-årig samfundsfagsstuderende, som blev døbt og konverterede til ZCC i 2006, efter at jeg havde lært ham at kende, er et godt udgangspunkt for at forstå, hvordan tilhængere af ZCC begrebsliggør sundhed og sygdom. Således berettede George for mig, hvordan han som den første i sin kernefamilie sluttede sig til ZCC, i forbindelse med at hans fars søskende og disses familier i hjemprovinsen efter hans overbevisning havde stået bag en række dårligdomme, som 
han selv og hans søster havde oplevet. I løbet af 2004, mens han var i gang med sin afsluttende skoleeksamen, blev George alvorligt syg, og hans forældre bragte ham til en kvindelig sangoma (traditionel healer), der forsøgte at helbrede ham med en række forskellige urter. George forklarer således:

Hun gjorde sine ting, men jeg kunne se, at hun ikke ville være i stand til at hjælpe mig, fordi hun ikke engang var bevidst om min tilstand: at jeg var i fare. Jeg kan mærke fare, for dem, der gjorde det her, de var folk fra min [udvidede] familie, så de havde været i gang længe. Deres målsætning var at sikre sig, at jeg ikke bestod min eksamen $[\ldots]$.

I et pragmatisk forsøg på at behandle hans tilstand blev George også taget til en praktiserende læge, som diagnosticerede hans hoste som en ordinær influenza og derfor udskrev nogle piller, som ikke hjalp spor. Georges egen fornemmelse var, at tilstanden var meget mere alvorlig og kompleks, end den praktiserende læge hævdede, og at hekseri var forklaringen på hans skrøbelige helbred. Når han overvejede, hvad de mistænkte familiemedlemmer bag hekserierne ønskede at opnå, formodede George, at de ville sikre sig, at Georges kernefamilie ikke havde fremgang og succes:

Faktisk, så ønskede de at gøre hele familien til grin, fordi det er, hvad der sker for mange familier, hvor jeg kommer fra. De fleste mennesker opnår ikke noget. Det er ikke, fordi de ikke er kloge [...] Der er faktisk mange begavede mennesker, men den her ting, hekseri, den stopper dem. Det er den store forhindring i vores område. For du kan se en person, som har et potentiale, men når han går til eksamen, så sker der mange ting rundt om den person. Måske begynder han at drikke og gøre mange negative ting, og vedkommende ender med at svigte sit potentiale.

George forklarede videre, hvordan hans svigtende helbred havde fået hans mor til at frygte, at han ville lide den samme kranke skæbne som sin storesøster. Den ulykkelige historie lød, at søsteren fødte et spædbarn, som døde af en uspecificeret sygdom kort efter fødslen, hvorefter hun selv døde efter kort tids sygdom i år 2000. I lyset af den sydafrikanske hiv-prævalens er det ikke usandsynligt, at Georges søster døde af aids-relaterede symptomer i en biomedicinsk forstand, alt imens det i Georges erfaring fremstår som to dødsfald, der må henføres til de udvidede familiemedlemmers misundelse og de forbandelser, som de har nedkaldt over Georges nære familie gennem aktiv brug af hekseri. I forhold til hans egen sygdom spurgte jeg George, om han ikke var bange for, at det var relateret til tuberkulose eller hiv, men da den praktiserende læge ikke havde kunnet kurere hans hoste, var han overbevist om, at det var på grund af hekseri og forbandelse. For at beskytte sig mod disse farer var George altså blevet en del af Den Zionistiske Kristne Kirke, som indgød ham nyt mod og håb, som det fremgår af næste afsnit. 


\section{Tvivl og håb}

Georges perspektiv på sygdommen var bundet op på det faktum, at han efter at være konverteret til ZCC i december 2006 mere eller mindre havde afsvoret enhver form for biomedicinsk forståelse af sygdom, fordi ZCC som en afrikansk kirke fokuserer på åndebesættelser og symbolske urenheder (se Sundkler 1961:2267; Comaroff 1985:201). Dette gjorde mit spørgsmål om tuberkulose og hiv/aids akavet og overflødigt. Siden sin konvertering til ZCC havde George oplevet en generel fremgang i sin helbredstilstand, og for at gennemgå en lang række renselsesritualer i kombination med bøn og indtag af store mængder vand og kold te ${ }^{4}$ tilbragte han en del af universitetets halvanden måned lange vinterpause i ZCC's religiøse by Moria, som ligger få kilometer fra Turfloop campus. Ved senere lejligheder har jeg kørt George til Moria, for at han kunne købe varer som te, kaffe og madolie, der er velsignet af kirkens præster, hvilket betyder, at de anses for at besidde helbredende egenskaber. Før man kan komme ind i Moria, skal man gennemgå en række renselsesritualer, hvor en præst sprøjter små mængder vand på én, brænder små papirer i umiddelbar nærhed af ens krop, slår én let med en lille kvist og serverer store mængder kold te. Til de andagter, der afholdes af ZCC-menigheden på Turfloop campus, sprøjtes der ligeledes små mængder vand på deltagerne, eftersom den underlæggende idé er, at mennesket er beskidt i forståelsen af hede og symbolsk urenhed, hvilket nødvendiggør afkøling med rensende vand (jf. Hammond-Tooke 1993:181-2; Douglas 1966:171). I forlængelse af en sotho-forståelse af urenhed er der et forbud mod at gå i kirke, hvis man befinder sig i en tilstand af urenhed eller hede, hvilket er tilfældet, hvis man for nylig har haft sex, hvis en kvinde menstruerer, eller hvis man for nylig har været til begravelse eller har mistet en nær slægtning (Hammond-Tooke 1993:181).

I forbindelse med ZCC's andagter bliver individuelle medlemmer af forsamlingen til profeter gennem en kortvarig åndebesættelse, hvor den besatte person udpeger en modtager af en besked ved at klappe i hænderne foran denne person. Eftersom den besatte person ofte taler i tunger, udpeges en tredjepart til at påtage sig rollen som mellemmand. I ZCC's kirke på Turfloop campus føres man derefter til et lille rum bagest $i$ bygningen, hvor man - omringet af andre profeter, modtagere og mellemmænd - danner en lille cirkel på gulvet, læner sig forover på knæene med hænderne foldet foran sig, alt imens profeten afleverer sit budskab gennem den besatte person i en eksalteret stemme. Den fortolkende mellemmand foretager samtidig oversættelse og har efterfølgende den opgave at nedfælde på papir, hvilke remedier fra ZCC der nu skal indkøbes til de daglige ritualer, der skal modvirke eller forebygge den tilstand, som profeten har forudset. Andagten er en ganske åben proces, hvor der er rum for individuel involvering og intersubjektiv fortolkning i konstruktionen af viden om en given tilstand. 
Diagnosen synes ikke at producere vished om årsagen til en dårligdom, snarere er det sådan, at profetens besked genererer en form for vished i forhold til, hvilke handlinger man nu nødvendigvis må skride til.

Som antropologen Jean Comaroff har pointeret, er disse vidnesbyrd i Den Zionistiske Kristne Kirke det umiddelbare udtryk for en virkelighed, der opfattes holistisk, og for et meningssystem, der ikke adskiller viden fra erfaring (Comaroff 1985:232). Strukturelt er dette meget lig de konsultationer hos traditionelle behandlere, som antropologen Susan Whyte har beskrevet fra det østlige Uganda, hvor uvished håndteres, ved at behandleren anviser en vej fremad ved at fortælle folk, hvilke handlinger de skal udføre (Whyte 1997:4). Som i Georges tilfælde udleder folk i det østlige Uganda heller ikke uden videre en diagnose fra en given ramme af viden eller social mening, men finder sig selv kastet ind i en proces af aktiv betydningsskabelse, hvor de trækker på multiple kilder og forståelsesrammer og afprøver forskellige behandlere, indtil de når et tilfredsstillende niveau af vished og lindring.

I nogle tilfælde sker det også, at uvishedens åbenhed foretrækkes frem for vished og kontrol, sådan som antropologerne Richard Jenkins, Hanne Jessen og Vibeke Steffen skriver i introduktion til deres antologi om sygdom, risiko og kampen for kontrol (Jenkins et al. 2005:9). I en artikel i den samme antologi foreslår Whyte, at i en verden karakteriseret ved uvished kan den grammatiske form ønskemåde være analytisk interessant, da den kan bruges til at betegne den tilstand af tvivl, håb, vilje og potentiale, i hvilken folk går til de problemer, som betyder mest for dem (Whyte 2005:251). Ønskemåde er den bøjningsform for verber, der indikerer håb og uvished, sådan som det kendes fra udsagnet: Kongen længe leve! På denne vis kan man anskue ønskemåde som det modsatte af de fakta, visheder og imperativer, som er målet for undersøgelser i vestlig biomedicin. Begrebet kan således være nyttigt, når vi skal udrede, hvad mange forskere og iagttagere har fundet svært at forstå i forhold til hiv og aids i Sydafrika: hvorfor så mange sorte sydafrikanere ikke ønsker at kende deres hiv-status.

\section{Test som hindring for tilblivelse}

I løbet af de år, hvor det sydafrikanske sundhedsministerium afviste at udbrede antiretroviral (ARV) medicin gennem de offentlige sundhedscentre (Nattrass 2007: 91-127; Thornton 2008:171-93; Fourie 2006:162-6), blev det ofte fremhævet, at det var nytteløst for folk at kende deres status, eftersom behandlingsmuligheder i form af ARV-medicin ikke var tilgængelige (jf. Le Marcis \& Ebrahim-Vally 2005:217). I et forsøg på at undersøge denne tankegang satte etnograf og journalist Jonny Steinberg sig for at studere en landsby i den østlige Kap-provins, hvor 
folk bor inden for gåafstand af gode og gratis behandlingstilbud (Steinberg 2009: 3). Steinberg blev gode venner med en ung mand, Sizwe, som var en fremgangsrig forretningsdrivende, som selv nærede en mistanke om, at han levede med hiv, men som vedvarende undgik at lade sig teste ved det nærliggende testcenter drevet af organisationen Læger Uden Grænser:

Hvis jeg ved, at jeg er hiv-positiv, vil jeg ikke længere være motiveret til at gøre de ting, som jeg gør nu, jeg mener, det, jeg gør lige nu, hvor jeg har tilbragt morgenen sammen med dig - hvor jeg investerer al min energi, hvert et minut af min vågne tid i min forretning. Det vil være meningsløst for mig. Jeg ville bare blive i sengen om morgenen (Steinberg 2009:342).

Med henvisning til en lignende tankegang sagde mange af de studerende, som jeg interviewede på Limpopo Universitet, at en person ikke dør af hiv-virus i sig selv, men at lige så snart man ved, at man lever med virus, vil man dø af bekymring, fordi visheden om at have hiv i kroppen vil fremme det tempo, hvormed man dør. På dansk modsvares disse udsagn af mundheldet: Hvad man ikke ved, har man ikke ondt af. Makgotla, som også blev citeret ovenfor, forklarede desuden:

Vi unge, vi tror, at hvis nogen er hiv-positiv, så betyder det, at denne fyr ... han er ved at dø [...], og at han ikke kommer til at leve ret meget længere. Vores formodning er, at hvis du er hiv-positiv, så er et år alt for lang tid for dig. Det øjeblik, du hører, at du er hiv-positiv, så lægger det sig i dit hjerte. Nu skal du dø.

Den samme pointe blev fremført af Tlhokomelo, en 22-årig kvindelig studerende, da hun sagde:

Vi er ikke bange for at gå til sundhedscentret. Vi er bange for testresultatet, fordi vi ender med at dø af den stress, der følger med hiv. Vi er ikke bange for hiv, men for frygten.

De studerende fortalte mig ofte om, at de havde været på sundhedscentret for at få taget en test, men at de så alligevel undlod at gå tilbage efter testresultatet. Dette var et mønster, som blev bekræftet ved universitetets eget sundhedscenter, hvor kun én ud af fem kom tilbage for at modtage resultatet af sin hiv-test (Limpopo Reader 2004:31). Blandt de 1.823 førsteårsstuderende ved Limpopo Universitet, som deltog i en spørgeskemaundersøgelse, var det kun 17,5 procent af de unge kvinder og 17,2 procent af de unge mænd, som nogensinde havde taget en hiv-test.

Det var overraskende, at de studerende vedholdende understregede ønsket om ikke at kende deres status, snarere end at de udtrykte ønsket om ikke at være inficerede eller om at få adgang til behandling. Særligt overraskende var det, fordi Mankweng Hospital lige ved siden af universitetet drev en hiv/aids-klinik, 
hvor man både kunne blive testet og fra 2004 modtage medicinsk behandling med ARV. De forklaringer, som jeg blev præsenteret for, kredsede ofte om, at man som ung ikke kunne håndtere, hvad der blev set som en hiv-tests endegyldige vished. Det følgende uddrag fra mit interview med Makgotla giver et klart indtryk af hans frygt for at tage en test:

Jeg er bare bange. Hvis jeg gik derhen og fandt ud af, at jeg var positiv, hvad ville der så ske? Mit liv ville have været spildt! Jeg er bange. Jeg vil gå derhen en dag, når jeg er parat til at tage mit forhold til det næste stadie og få et barn. For at få det perspektiv på tingene, før vi gør det uden kondom [...] Jeg går derhen en dag. Jeg prøver stadig. I 2005 gik jeg til sundhedscentret for at få vejledning og test, og man skulle komme tilbage for at få resultatet. Jeg bestemte mig for ikke at gå tilbage, selv om sundhedsvejlederen fortalte mig om alle fordelene for dem, der viser sig at være positive. Jeg vil hellere leve og ikke vide noget [...] Prøv lige at tænke på det. Hvad skal jeg sige til mine forældre? Hvad skal jeg sige til mine venner? [...] Det er ikke nemt. Jeg er bange. Måske en dag - men ikke særlig snart. Lad os håbe - en dag.

Makgotlas frygt er både internt og eksternt begrundet, eftersom han på den ene side peger på det sociale stigma, som han formentlig ville opleve fra sine slægtninge og venner, mens han på den anden side bekymrer sig om, at en positiv test vil forvandle hans liv til noget, der er blevet spildt, og noget, der forhindrer ham $i$ at opnå en fuldbyrdet position som voksen med kone og barn. I forhold til Kifilwes case er det i denne forbindelse interessant, at mænd ikke på samme måde som kvinder fordømmes på grund af deres seksuelle fortid, fordi mænd almindeligvis vinder prestige og status gennem seksuelle relationer (Oxlund 2009b:106; se også Tersbøl 2006:413). Til gengæld påvirkes mændenes sociale fremtid og moralske horisont i samme omfang som kvindernes af en positiv hivtest, fordi det vil forhindre dem $i$ at fuldbyrde deres sociale status med en stor familie og børneflok, der kvalificerer dem til status af en forfader, den dag de dør (Oxlund 2009b:103). Derfor udskyder Makgotla hiv-testen til engang i den fjerne fremtid, hvor han vil skulle udrede sin status, inden han kan gifte sig og forhåbentlig planlægge familieforøgelse. Det er tankevækkende, at Makgotla ikke blankt afviser tanken om at tage en hiv-test. Han har allerede været af sted én gang og udtrykker håb om at finde modet til at gå tilbage efter testresultatet en dag. Uvisheden udtrykker han ved gentagne gange at sige „Jeg ved det ikke“, mens håbet interessant nok udtrykkes i ønskemåde: „Lad os håbe - en dag.“ I det følgende afsnit skal vi se, hvordan dette håb hænger sammen med lokale forståelser af samspillet mellem krop og psyke. 


\section{Lokale forståelser af krop og psyke}

På det lokale sotho-sprog opdeles en person i fire forskellige komponenter: blodet (inkluderer også sæd), kødet, ånden og skyggen (madi, mmele, moya og seriti), hvor det er ånden og skyggen, der udgør de reelt livgivende enheder. I sin monografi om den sotho-talende etniske gruppe pedi skrev Hans Otto Mönnig, at ved en persons død forlader hans ånd og skygge kroppen, som nu er en tom størrelse, der bare skal falde fra hinanden. Dette til trods vedbliver ånden og skyggen med at fortsætte deres eksistens som en samlet enhed, i hvilken moya knytter sig til seriti på den samme måde, som den plejede at knytte sig til den fysiske krop (Mönnig 1967:53). I litteraturen er seriti beskrevet som et sjæleligt begreb, der bedst kan forstås som et menneskes personlighed og moralske styrke, mens moya er blevet fortolket som livskraften, der løber gennem hele kroppen (Hammond-Tooke 1993:149). I livsforløbet er moya altid forbundet med kroppen, mens forbindelsen mellem seriti og kroppen kan variere fra situation til situation, eftersom skyggen kan vandre (Mönnig 1967:50).

På denne måde er det skyggen, der gør den enkelte person åben og gennemtrængelig for andre menneskers intentioner, fordi de kan påvirke den med ondt for øje (ibid.51). Fremkomsten af sygdom og dårligdom kan følgelig forstås som en konsekvens af situationer, hvor udvekslingen af kropsvæsker finder sted i en tilstand af rituel urenhed, som bringer en person i kontakt med en forurenende seriti og dårligt blod, eller når nogen forsøger at skade en person ved at påvirke hans eller hendes seriti negativt. Det interessante i denne sammenhæng er, at den ætiologi, som den firfoldige begrebsliggørelse af mennesket etablerer i forhold til sygdom og dårligdom, ikke nødvendigvis er så forskellig fra en medicinsk forståelse af hiv, som det ofte hævdes (se fx Ashforth 2002).

Hvis man tænker på hiv-inficeret blod som dårligt blod (madi), på psykosocial modstandskraft og styrke som seriti, på immunforsvaret som moya og endelig på mmele som den fysiske krop, er kontrasterne slet ikke uoverkommelige. Lokale forståelser af sammenhængen mellem krop og psyke og biomedicinske forklaringer behøver derfor ikke at udelukke hinanden, men kan være samtidigt eksisterende i den enkelte persons pragmatiske forsøg på at finde en forklaring på sygdom og dårligdom. Knytter man de studerendes vage kommentarer om, at de dør af bekymring, eller at de frygter at kende deres status, bliver det muligt at forstå deres udsagn således: De studerende tror på, at hiv/aids overføres på de måder, som det beskrives i de nationale hiv- og aids-kampagner, men den gradvise og uigennemsigtige proces, hvorved helbredet bliver dårligere på grund af immunforsvarets svækkelse, bliver mere meningsfuld, når den samtidig kan forstås som interaktionen mellem en svækket seriti og en moya, der efterfølgende svækkes. Visheden om, at man lever med hiv, vil fundamentalt erodere ens seri- 
ti og føre til en hurtig død, hvilket mange studerende anfører som grunden til, at de helst vil vente med at tage en hiv-test, til de har synlige symptomer på aids på deres krop. Ved at forblive i ønskemåde, som i denne forbindelse altså er en tilstand af ikke at kende sin hiv-status, bliver den enkelte i stand til at styrke og beskytte sin seriti, mens den vished, som en positiv hiv-test ville afstedkomme, forhindrer dette. Som det også fremgik af Makgotlas kommentarer, er den temporale dimension en vigtig faktor i den enkeltes vilje til eller uvilje mod at føre en hiv-test til ende. Dette stemmer overens med Susan Whytes observationer fra Uganda:

Når folk i Bunyole siger, at nogen er syg med aids, forudsætter de, at personen er dødeligt syg og formodentlig ikke kan kureres. Når de siger, at nogen er påvirket af ånder eller hekseri, er det også en måde, hvorpå de foreslår, at noget kan gøres for at afhjælpe situation (Whyte 2005:257; min oversættelse).

Whyte skriver videre, at i Bunyole er det derfor prognosen snarere end måden, hvorpå hiv blev overført, der er årsag til stigma (ibid.), hvor jeg for Limpopos vedkommende vil mene, at stigma er forårsaget af begge forhold, eftersom en positiv hiv-test har potentialet til at omdefinere både den enkeltes fortid og fremtid. Douglas har i denne sammenhæng påpeget, at det ofte afgøres post hoc, hvorvidt brud på de moralske regler har fundet sted (Douglas 1966:165), dvs. en positiv hiv-test er et vidnesbyrd om, at de moralske regler er blevet overskredet, og at forurening har fundet sted.

Dette gælder også i forhold til de individuelle historier, som jeg har præsenteret i denne artikel. I Kifilwes tilfælde viste jeg, at hendes kolleger fortolkede hendes fysiske svækkelse som en konsekvens af en tilstand af hede (fiša), der havde afstedkommet en tilstand af urenhed (ditšhila), som i sidste ende havde fået hende til at tabe den kombinerede styrke af ånd og skygge. Den samme form for bagklogskab gør sig gældende i Makgotlas frygt. En hiv-positiv test ville ikke bare være en diagnose for lige nu og her. Den ville samtidig være en moralsk dom over hans fortid og en grum prognose for hans fremtid, hvor han ikke ville kunne få børn og stifte familie, hvilket i en sotho-optik er den eneste måde, hvorpå man kan blive til en hel og fuld person. Disse indsigter hjælper os tættere på en forståelse af, hvorfor så mange sydafrikanere ikke ønsker at blive testet for hiv. I mange tilfælde foretrækker folk en uvished og åbenhed frem for vished og biomedicinske konklusioner. Set i dette lys kan uviljen mod at lade sig teste ikke bare anskues som individuel benægtelse (jf. Le Marcis \& EbrahimVally 2005:226), men må i stedet tolkes som en følgevirkning af folks frygt for de sociale, fysiske og psykiske konsekvenser af at kende deres potentielle hivpositive status. 


\section{Konklusion: Frygten for social død}

Denne artikel har søgt at vise, hvordan hiv og aids anskues som en moralsk fare i konkrete sociale miljøer i Sydafrika. Dette perspektiv er på én og samme tid bredere og mere præcist end den universelle og individualistiske forståelse af hiv-relateret stigma, som mange forskere og udviklingsprogrammer har trukket på med inspiration fra Goffman. Ligeledes er den sydafrikanske respons på hiv og aids ofte blevet beskrevet med henvisning til benægtelse, men dette begreb, som er hentet fra den individorienterede psykologi, dækker i meget ringe grad de komplekse forhold, som gemmer sig under den sociale respons på hiv og aids. Imidlertid præsenterer den sydafrikanske situation på mange måder et paradoks, eftersom offentligheden bombarderes med oplysningsmaterialer, kampagner og plakater, alt imens epidemien håndteres med tavshed og omgåelsesmanøvrer på lokalsamfundsniveau. Ved at inddrage perspektiver fra den klassiske antropologi om urenhed og dårligdom har jeg derfor ønsket at vise, hvordan tavshed og omgåelse kan være strategier, der sigter mod at opretholde et ønskværdigt niveau af uvished og åbenhed, som sætter folk i stand til uanfægtet at leve deres liv så længe som muligt. Til trods for, at ARV-medicin i stigende omfang er blevet tilgængelig fra sydafrikanske regeringshospitaler, tolkes en positiv hiv-test stadig som et signal om en snarlig død. Samtidig er det sådan, at ved at undgå testen undgår man samtidig den moralske dom fra lokalsamfundets side, som er et meget sandsynligt udfald af en positiv hiv-test. Når de studerende talte om disse størrelser, trak en række studerende på en forklaringsramme, hvor en person er åben og gennemtrængelig for hekseri eller forurening forårsaget af overtrædelser af moralske regler. Ifølge disse studerende var det at kende sin positive hiv-status i sig selv stærkt svækkende for livskraften og accelererende for den dødelige proces, som aids i udbrud fører med sig, når den ikke behandles. Som dokumenteret gennem uddrag fra fortællingerne om Kifilwe, Makgotla og George anses det for gavnligt ikke at have vished om ens hiv-status i en biomedicinsk forstand. Denne tilstand af uvished og håb, som jeg med inspiration fra Whyte kaldte for ønskemåde (2005:251), viste sig at være analytisk nyttig i forhold til at forstå, hvorfor et flertal af studerende ved Limpopo Universitet har mange forbehold over for at lade sig teste for hiv, og hvorfor de generelt forholder sig til hiv og aids med tavshed.

Til trods for de interessante politiske slagsmål om hiv og aids i Sydafrika har artiklen således demonstreret vigtigheden af på et hverdagsniveau at undersøge, hvordan folk søger at leve moralske liv i en lokal verden præget af den usikkerhed og uvished, som en hiv- og aids-epidemi fører med sig. De forskellige personlige historier analyseret i denne artikel vidner om, at hiv og aids ikke blot er en trussel mod kroppen. En positiv hiv-test truer samtidig med at udviske og 
slette den enkelte person og præmaturt afslutte vedkommendes sociale tilblivelsesproces. Dette minder om, hvad antropologen Isak Niehaus har kaldt for død før døden (Niehaus 2007:845), eller hvad Henrik Vigh kalder for social død (Vigh 2006:103). En positiv hiv-test gør det næsten umuligt for en ung person at udvikle sig på en måde, som vil gøre vedkommende værdig til anerkendelse som et moralsk individ i sin umiddelbare sociale kontekst. Konfronteret med dette skisma er ønskemåde klart at foretrække, og således bliver tavsheden i relation til hiv og aids konfigureret og opretholdt gennem de interaktioner, som folk har med hinanden hver eneste dag, og hvor de søger at håndtere frygten for social død gennem tavshed og omgåelse.

\section{Noter}

1. Ætiologi er læren om sygdomme.

2. TAC's succes og store udbredelse i byområderne synes at tale imod denne artikels pointer om tavsheder, men på mange måder bekræfter TAC's aktiviteter diskrepansen mellem højlydte hiv/aids-kampagner og tavshed og omgåelse i lokale fællesskaber - navnlig i mere landlige områder.

3. En almindeligt anvendt lindringsform blandt tilhængere af den uafhængige afrikanske kirke, Zionist Christian Church (ZCC).

4. ZCC opererer med en definition af sundhed som den fri cirkulation af kropsvæsker, der fremmes gennem indtag af store mængder vand og kold te (jf. Comaroff 1985:234).

Søgeord: hiv, aids, tavshed, social død, stigma, Sydafrika

\section{Litteratur}

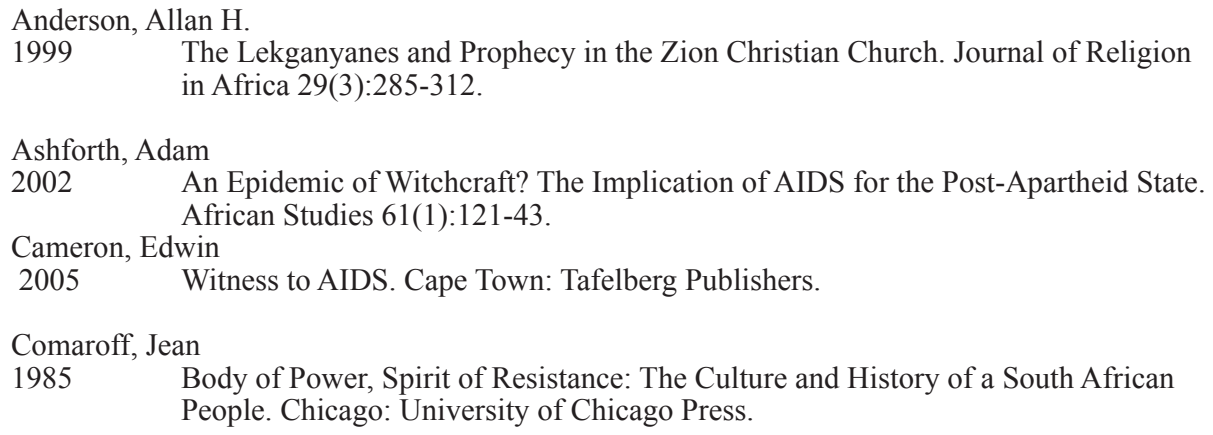

Das, Veena

2001 Stigma, Contagion, Defect: Issues in the Anthropology of Public Health. Stigma and Global Health: Developing a Research Agenda (an international conference). Bethesda Maryland, USA. 
Delius, Peter \& Clive Glaser

2005 Sex, Disease and Stigma in South Africa: Historical Perspectives. African Journal of AIDS Research 4(1):29-36.

$\mathrm{DoH}$

2006 National HIV and Syphilis Ante-natal Sero-prevalence Survey in South Africa 2005. Pretoria: Epidemiology and Surveillance, Department of Health.

Douglas, Mary

1966 Purity and Danger. An Analysis of Concepts of Pollution and Taboo. London: Routledge \& Kegan Paul.

Durden, Emma

2008 Evaluation DRAMAIDE's Health Promotion Programme in Higher Education Institutions. Johannesburg: USAID, PEPFAR and Johns Hopkins Health and Education in South Africa.

Evans-Pritchard, Edward Evan

1936 Wichcraft Oracles, and Magic among the Azande. Oxford: Oxford University Press.

Farmer, Paul

1992 AIDS and Accusation: Haiti and the Geography of Blame. Berkeley: University of California Press.

Forsyth, Brian, Alain Vandormael, Trace Kershaw \& Janice Grobbelaar

2008 The Political Context of AIDS-related Stigma and Knowledge in a South African Township. Journal of Social Aspects of HIV/AIDS 5(2):74-82.

Fourie, Peter

2006 The Political Management of HIV and AIDS in South Africa. Hampshire: Palgrave MacMillan.

Goffman, Erving

1963 Stigma: Notes on the Management of Spoiled Identity. Englewood Cliffs, N.J.: Prentice-Hall.

Hammond-Tooke, William D.

1981 Boundaries and Belief. The Structure of a Sotho Worldview. Johannesburg: Witwatersrand University Press.

1993 The Roots of Black South Africa. Johannesburg: Jonathan Ball Publishers.

Jenkins, Richard, Hanne Jessen \& Vibeke Steffen

2005 Matters of Life and Death. I: V. Steffen, R. Jenkins \& H. Jessen (eds.): Managing Uncertainty. Ethnographic Studies of Illness, Risk and the Struggle for Control. København: Museum Tusculanum Press.

Kalichman, Seth C., Leikness C. Simbayi, Sean Jooste, Yoesrie Toefy, Demetria Cain, Chauncey Cherry \& Ashraf Kagee

2005 Development of a Brief Scale to Measure AIDS-Related Stigma in South Africa AIDS and Behavior 9(2):135-43.

Kleinman, Arthur

1999 Moral Experience and Ethical Reflection: Can Ethnography Reconcile Them? A Quandary for "The New Bioethics". Daedalus 128(4):69-97.

2006 What Really Matters: Living a Moral Life amidst Uncertainty and Danger. Oxford \& New York: Oxford University Press. 
Leclerc-Madlala, Suzanne

2005 Popular Responses to HIV/AIDS and Policy. Journal of Southern African Studies 31(4):845-56.

Le Marcis, Frédéric \& Rehana Ebrahim-Vally

2005 People Living with HIV and AIDS in Everyday Conditions of Township Life in South Africa: Between Structural Constraint and Individual Tactics. Journal des Aspects Sociaux VIH/SIDA 2(1):217-35.

Limpopo Leader

2004 Health in SA's Higher Education: Fighting AIDS at Turfloop. Limpopo Leader no. 2.

Morrell, Robert

2003 Silence, Sexuality and HIV/AIDS in South African Schools. The Australian Educational Researcher 30(1):41-62.

Mönnig, Hans Otto

1967 The Pedi. Pretoria: JL van Schaik.

Nattrass, Nicoli

2004 The Moral Economy of AIDS in South Africa. Cambridge: Cambridge University Press.

2007 Mortal Combat. AIDS Denialism and the Struggle for Anti-retrovirals in South Africa. Scottsville: University of KwaZulu-Natal Press.

Ngubane, Harriet

1977 Body and Mind in Zulu Medicine: An Ethnography of Health and Disease in Nyuswa-Zulu Thought and Practice. London \& New York: Academic Press.

Niehaus, Isak

2001 Witchcraft in the New South Africa. From Colonial Superstition to Post-colonial Reality. I: H.L. Moore \& T. Sanders (eds.): Magical Interpretations, Material Realities. London and New York: Routledge.

2002 Bodies, Heat, and Taboos: Conceptualizing Modern Personhood in the South African Lowveld. Ethnology 41(3):189-207.

2007 Death before Dying: Understanding AIDS Stigma in the South African Lowveld. Journal of Southern African Studies 33(4):845-60.

Niehaus, Isak \& Gunvor Jonsson

2005 Dr. Wouter Basson, Americans, and Wild Beasts: Men's Conspiracy Theories of HIV/AIDS in the South African Lowveld. Medical Antropology 24(2):179-208.

Oxlund, Bjarke

2009a Love in Limpopo. Becoming a Man in a South African University Campus. Department of Anthropology. Ph.d.-rækken 54. København: Københavns Universitet.

2009b Kærlighedens topografi. Forskning som en rejse i et moralsk landskab. I: K Hastrup (red.): Mellem mennesker. En grundbog i antropologisk forskningsetik. København: Hans Reitzels Forlag.

Posel, Deborah

2004 "Getting the Nation Talking about Sex": Reflection on the Discursive Constitution of Sexuality in South Africa since 1994. Agenda 62:53-63.

2007 A Matter of Life and Death. I: L. McGregor \& S. Nuttall (eds.): At risk. Writing on and over the Edge of South Africa. Johannesburg and Cape Town: Jonathan Ball Publishers. 
Reid, Graeme \& Liz Walker

2003 Secrecy, Stigma and HIV/AIDS: An Introduction. African Journal of AIDS Research 2(2):85-88.

Robins, Sharon

2008 Rights. I: N. Shepherd \& S. Robins (eds.): New South African Keywords. Johannesburg: Jacana Media.

Stadler, Jonathan

2003 The Young, the Rich, and the Beautiful: Secrecy, Suspicion and Discourses of AIDS in the South African Lowveld. African Journal of AIDS Research 2(2):12739.

Steffen, Vibeke \& Hanne Jessen

2002 Kultur og sygdom - fra klassifikatorisk orden til kulturel kompleksitet. I: F. Alberdi, C. Nørregaard, M. Kastrup \& M. Kristensen (red.): Transkulturel psykiatri. København: Hans Reitzels Forlag.

Steinberg, Jonny

2009 Three Letter Plague. A Young Man's Journey through a Great Epidemic. London: Vintage Books.

Sundkler, Bengt

1961 Bantu Prophets in South Africa. London \& New York: Published for the International African Institute by the Oxford University Press.

Tersbøl, Britt Pinkowski

2006 "I just ended up here, no job and no health". Men's Outlook on Life in the Context of Economic Hardship and HIV/AIDS in Namibia. SAHARA-J: Journal of Social Aspects of HIV/AIDS 3(1): 403-16.

Thornton, Robert J.

2008 Unimagined Community Sex, Networks, and AIDS in Uganda and South Africa. Berkeley: University of California Press.

UNAIDS

$2010 \quad$ World Epidemic Update 2010. Geneva: UNAIDS and WHO.

van der Vliet, Virginia

2004 South Africa Divided against AIDS: A Crisis of Leadership. I: K.D. Kauffman \& D.L. Lindauer (eds.): AIDS and South Africa. The Social Expression of a Pandemic. Houndsmills, Basingstoke, Hampshire \& New York: Palgrave Macmillan.

Vigh, Henrik

2006 Social Death and Violent Life Chances. I: C. Christiansen, M. Utas \& H. Vigh (eds.): Navigating Youth, Generating Adulthood. Social Becoming in an African Context. Uppsala: Nordiska Afrika Institutet.

Whyte, Susan Reynolds

1997 Questioning Misfortune: The Pragmatics of Uncertainty in Eastern Uganda. Cambridge: Cambridge University Press. 
Uncertain Undertakings: Practicing Health Care in the Subjunctive Mood. I:

V. Steffen, R. Jenkins \& H. Jessen (eds.): Managing Uncertainty. Ethnographic Studies of Illness, Risk and the Struggle for Control. København: Museum

Tusculanum Press.

Zigon, Jarrett

Morality: An Anthropological Perspective. Oxford \& New York: Berg. 
